Chymotrypsin

elastase

human milk protease inhibi-

tors

trypsin

\title{
Protease Inhibitors in Human Milk
}

\author{
TOR LINDBERG \\ Departments of Pediatrics and Experimental Research, Malmö General Hospital, University of Lund, Malmö, Sweden
}

\begin{abstract}
Summary
Protease inhibitors (inhibiting trypsin, chymotrypsin, and elastase) were demonstrated in human milk from birth to 4 months after delivery. No pepsin inhibitor was found. The protease inhibitors were localized in the $\alpha_{1}$-region-inhibiting trypsin, chymotrypsin, and elastase - and in a more cathodal region-inhibiting chymotrypsin-in agarose gel electrophoresis of human milk. $\alpha_{1^{-}}$ antitrypsin and antichymotrypsin were demonstrated by crossed immunoelectrophoresis. Electroimmunoassay showed the concentration of $\alpha_{1}$-antitrypsin in 1st day milk to be $10.9 \%$ and the concentration of antichymotrypsin was $116 \%$ of that of adult serum. The concentrations decreased during the $1 \mathrm{st}$ wk; from 1 wk to 4 months they were $1.6 \%$ for $\alpha_{1}$-antitrypsin and $3.8 \%$ for antichymotrypsin of those of adult serum. One $\mathrm{ml}$ of human milk from the first 3 days inhibits, by enzymatic methods, 0-150 $\mu \mathrm{g}$ (mean value, $70 \mu \mathrm{g}$ ) trypsin. Milk from 1 week after delivery and later inhibits 0-65 $\mu \mathrm{g}$ (mean value, $38 \mu \mathrm{g}$ ) trypsin per $\mathrm{ml}$.
\end{abstract}

\section{Speculation}

Protease inhibitors are present in large amounts in, for example, bovine and porcine colostrum and play a role in the intestinal absorption of proteins, i.e., immunoglobulins, in the newborn animal. Although the concentration of protease inhibitors in human milk is much lower, they might play a role in the local immunity in the lumen of the gut and in the enhanced absorption of proteins occurring in early infancy.

Trypsin inhibitor in human and bovine colostrum was demonstrated in 1951 by Laskowski \& Laskowski (22). The bovine colostral trypsin inhibitor was later isolated and characterized, and isoinhibitors have been demonstrated $(2,9,10,19,27)$. Trypsin inhibitors and isoinhibitors were also demonstrated in colostrum from the pig $(5,6,8,20,21)$ and from the rat $(7,31)$. The general opinion is that the trypsin protease inhibitors in colostrum from these species play a role in the intestinal absorption of proteins, especially of immunoglobulins in the newborn animal (3).

Few studies have dealt with the trypsin inhibitors in human milk $(2,16,17)$. Data covering the occurrence, amounts, and properties of protease inhibitors in human milk from various periods of the lactation are incomplete. The physiologic role of the inhibitors in human milk is obscure.

The present study reports the occurrence, electrophoretic properties, and amounts of some protease inhibitors in human milk from birth to 4 months after delivery.

\section{MATERIALS}

Human milk was collected from healthy mothers on the 1st, 2nd, and 3rd day, and between 1 wk and 4 months after delivery. The samples were either analyzed directly or stored at $-20^{\circ} \mathrm{C}$ until analysis. Urine and serum samples from infants were stored at $-20^{\circ} \mathrm{C}$ until analysis. Porcine colostrum was kindly supplied by Dr B. W. Karlsson, Institute of Zoophysiology, University of Lund, Sweden.

Antihuman $\alpha_{1}$-antitrypsin, antihuman antichymotrypsin, and standard serum for the measurements of the concentration of $\alpha_{1}$ antitrypsin and antichymotrypsin were gifts of Dr P. Fernlund, Department of Clinical Chemistry, Malmö General Hospital. A standard pool of serum from 1000 donors was regarded as $100 \%$ $=$ about $1.35 \mathrm{~g} \alpha_{1}$-antitrypsin/liter and $0.5 \mathrm{~g}$ antichymotrypsin/ liter.

Chemicals: Agarose (Miles-Seravac, Maidenhead, England) casein (BDH), elastin (Worthington), N-benzoyl-DL-arginine-p-nitroanilide (BAPNA) (Sigma), bovine trypsin (EC 3.4.4.4.) (Fluka), $\alpha$-chymotrypsin (EC 3.4.4.5) (Fluka), pepsin (EC 3.4.23.1) (Fluka), and elastase (EC 3.4.4.7) (Sigma).

\section{METHODS}

\section{DEMONSTRATION OF PROTEASE INHIBITORS}

Trypsin, chymotrypsin, elastase, and pepsin inhibitors were detected by means of agarose gel diffusion in combination with agarose gel electrophoresis (4). A microscope slide with a gel containing $2.25 \%$ agarose and $0.1 \%$ casein was immersed for 45 min in buffer (for trypsin and chymotrypsin $0.05 \mathrm{M}$ trisbuffer, $\mathrm{pH}$ 7.9 containing $0.22 \mathrm{M} \mathrm{CaCl}_{2}$, for pepsin acetate-hydrochloric acid buffer, $\mathrm{pH} 2$ ). For elastase, the gel contained $0.8 \%$ agarose and $0.6 \%$ elastin in $0.1 \mathrm{M}$ trisbuffer $\mathrm{pH}$ 8.6. Enzyme solution (trypsin $0.05 \mathrm{mg} / \mathrm{ml}$ of $0.001 \mathrm{M} \mathrm{HCl}$, chymotrypsin $0.1 \mathrm{mg} / \mathrm{ml}$, elastase $0.05 \mathrm{mg} / \mathrm{ml}$, and pepsin $0.1 \mathrm{mg} / \mathrm{ml}$ ) was poured into a central trough in the gel. An agarose gel electrophoretic strip of, e.g., human milk was immediately laid on the agarose-substrate gel on each side of the trough. After incubation for $4 \mathrm{hr}$ (trypsin, chymotrypsin, pepsin) and $18 \mathrm{hr}$ (elastase) at $37^{\circ} \mathrm{C}$, the slide was immersed in $2 \%$ acetic acid for $1 \mathrm{hr}$, dried, and the caseincontaining slides were stained with amido black. Undigested casein is stained dark blue (black in photos), whereas digested casein gives no stain (see Fig. 1). Elastolytic activity is seen without staining as a clear zone in the densely opalescent elastin-agarose.

\section{ELECTROPHORESIS AND IMMUNOELECTROPHORESIS}

Agarose gel electrophoresis (18), crossed immunoelectrophoresis $(13,23)$, and electroimmunoassay $(24,25)$ were performed with $0.075 \mathrm{M}$ barbital-sodium barbital buffer, $\mathrm{pH} 8.6$, containing 0.002 $M$ calcium lactate.

\section{QUANTITATIVE DETERMINATION OF TRYPSIN-INHIBITING ACTIVITY}

The inhibiting capacity of centrifuged (defatted) human milk against bovine trypsin was determined using BAPNA as substrate $(6,12)$.

\section{RESULTS}

\section{DEMONSTRATION OF PROTEASE INHIBITORS}

Figure 1 shows the trypsin inhibiting activity in porcine colostrum, in human milk from the 2 nd day, and in serum and urine from the 2-day-old infant. The trypsin inhibitors have different electrophoretic mobility in the various samples. In the porcine colostrum, they are localized in the $\gamma$-region; in human milk and 


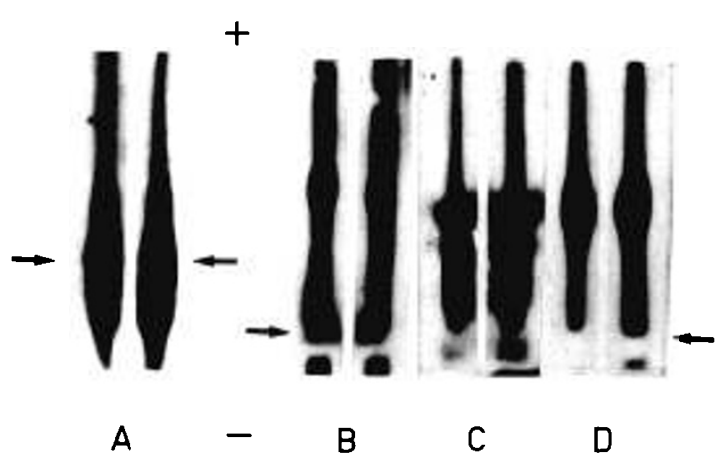

Fig. 1. Protease inhibiting activity detected by agarose gel electrophoresis $(\mathrm{pH} 8.6)$ in combination with gel diffusion. The trough contains trypsin. $A$. Porcine colostrum. $B$. Human milk from 2 nd day after delivery. $C$. Serum from a 2-day-old infant. $D$. Urine from a 2-day-old infant. Arrow indicates site of application at electrophoresis. Protein stain: Comassie Brilliant Blue R-250.

in the urine of the infant, in the $\alpha_{1}$-region; and in the infant's serum in the $\alpha_{1^{-}}$and $\alpha_{2}$-regions. All serum and urine samples from a further 15 infants, 0- to 3-days-old, showed a trypsin inhibiting capacity with the same electrophoretic mobility as in Figure 1, irrespective of whether the samples were taken before or after the infant's first breast meal.

Twenty samples of human milk were heated for $10 \mathrm{~min}$ in boiling water: trypsin inhibiting capacity disappeared in 14 samples and diminished in 6 .

There was no difference in trypsin inhibiting capacity between centrifuged (defatted) and noncentrifuged milk.

The electrophoretic mobility of chymotrypsin and elastase inhibitors was similar to that of the trypsin inhibitors, except that 5 of 10 samples from the first 2 days, another inhibiting activity against chymotrypsin was detected, localized cathodally to the other. Milk from day 3 or later had this inhibiting activity in 3 of 18 samples. Pepsin inhibitor could not be demonstrated.

Table 1 summarizes the results.

\section{IMMUNOELECTROPHORESIS STUDIES}

Figure 2 shows the crossed immunoelectrophoresis of human milk from the 1st, 2nd, and 3rd day after delivery against antihuman $\alpha_{1}$-antitrypsin and antihuman antichymotrypsin. The concentrations of $\alpha_{1}$-antitrypsin and antichymotrypsin decrease during these 3 days. The protein band in electrophoresis corresponding to $\alpha_{1}$-antitrypsin is distinct in the samples from the 1st day, faint from the 2 nd, and hardly visible from the 3 rd day. The crossed immunoelectrophoresis showed in some cases an asymmetric precipitate of $\alpha_{1}$-antitrypsin with an irregular cathodal slope indicating microheterogeneity. Two components of antichymotrypsin were found, one minor in the $\alpha_{2}$-region and one major with a slower electrophoretic mobility.

Figure 3 shows the contents of $\alpha_{1}$-antitrypsin and antichymotrypsin in human milk at varying times after delivery, determined with the electroimmunoassay technique. The concentration is related to that in human serum. During the first 3 days the amount of antichymotrypsin was higher than that of $\alpha_{1}$-antitrypsin.

\section{TRYPSIN INHIBITING CAPACITY OF HUMAN MILK}

Trypsin, $0.95 \mathrm{~g}$, is inhibited to $90-95 \%$ by $\alpha_{1}$-antitrypsin/liter human plasma (11). Thus, from the results in Figure $3, \alpha_{1}$-antitrypsin in $1 \mathrm{ml}$ of human milk from the various times after birth theoretically should inhibit about $95,45,40$, and $15 \mu \mathrm{g}$ of trypsin, respectively. The spectrophotometric method with BAPNA as substrate produced the following values: $1 \mathrm{ml}$ of milk from nine mothers from the first 3 days inhibited: 150,30 , and $30 \mu \mathrm{g}(0-24$ $\mathrm{hr}) ; 95$ and $0 \mu \mathrm{g}(24-48 \mathrm{hr}) ; 140,55,55$, and $0 \mu \mathrm{g}(48-72 \mathrm{hr})$ of bovine trypsin (mean value, $70 \mu \mathrm{g}$ ). During the later part of the lactation period ( 1 wk to 4 months), $1 \mathrm{ml}$ inhibited 0-65 $\mu \mathrm{g}$ trypsin (mean value: $38 \mu \mathrm{g}, n=9$ ).

\section{DISCUSSION}

The dominant protease inhibitors in plasma against trypsin, chymotrypsin, and elastase are $\alpha_{1}$-antitrypsin and $\alpha_{2}$-macroglobulin. Antichymotrypsin in plasma is of minor importance as a protease inhibitor $(26,29)$.

This study has shown that human milk from birth to 4 months after delivery inhibits the proteolytic activity of trypsin, chymotrypsin, and elastase. The inhibitor against these enzymes is electrophoretically localized in the $\alpha_{1}$-region and also in a more cathodal region against chymotrypsin, in contrast to that in porcine colostrum where it is found in the $\gamma$-region (5). No inhibiting activity against trypsin and elastase could be detected in the $\alpha_{2^{-}}$ region in the electrophoresis of human milk. This agrees with reports that $\alpha_{2}$-macroglobulin is not found in human milk $(14,15)$. In serum from infants, trypsin inhibiting activity was detected in the $\alpha_{1-}$ and $\alpha_{2}$-region, but in urine in the $\alpha_{1}$-region only. The pattern was the same irrespective of whether the samples were taken before or after the infants' first breast meal. However, as we have no quantitative data of the trypsin inhibitors in urine, it remains to be shown if intestinal absorption and urinary excretion of milk trypsin inhibitors as found in the newborn pig $(1,8)$ occurs in the newborn infant.

Table 1. Occurrence of Protease Inhibiting Activity of Human Milk At Various Times After Delivery

\begin{tabular}{ccccc}
$\begin{array}{c}\text { Time } \\
\text { after } \\
\text { delivery }\end{array}$ & $\begin{array}{c}\text { Trypsin } \\
\text { inhibiting } \\
\text { activity }\end{array}$ & $\begin{array}{c}\text { Chymo- } \\
\text { trypsin } \\
\text { inhibiting } \\
\text { activity }\end{array}$ & $\begin{array}{c}\text { Elastase } \\
\text { inhibiting } \\
\text { activity }\end{array}$ & $\begin{array}{c}\text { Pepsin } \\
\text { inhibiting } \\
\text { activity }\end{array}$ \\
\hline $0-24 \mathrm{hr}$ & $6 / 12^{1}$ & $4 / 7$ & $3 / 5$ & $0 / 6$ \\
$24-48 \mathrm{hr}$ & $8 / 12$ & $3 / 3$ & $3 / 3$ & $0 / 3$ \\
$48-72 \mathrm{hr}$ & $12 / 13$ & $6 / 6$ & $6 / 6$ & $0 / 6$ \\
I wk-4 months & $34 / 34$ & $11 / 12$ & $10 / 11$ & $0 / 11$ \\
\hline
\end{tabular}

'No. of samples showing inhibiting activity/no. of samples analyzed.

A

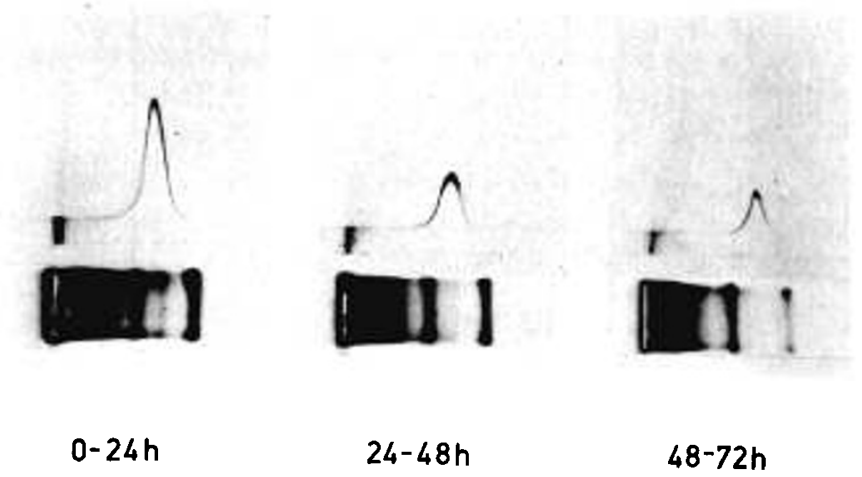

B

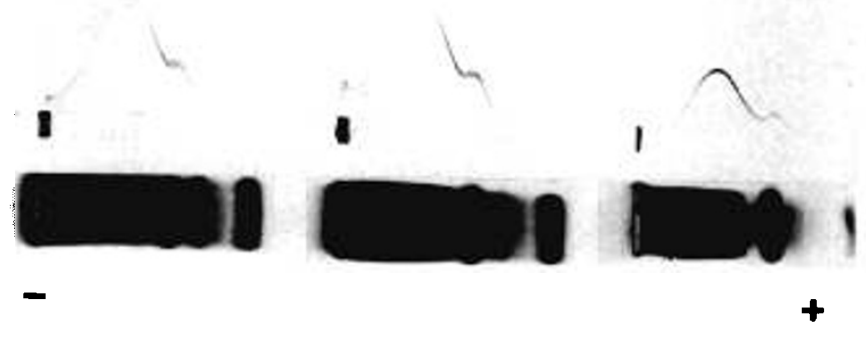

Fig. 2. Crossed immunoelectrophoresis showing $\alpha_{1}$-antitrypsin (A) and antichymotrypsin (B) in human milk from 0-24, 24-48, and 48-72 hr after delivery. The agarose gel electrophoresis of the corresponding samples is given for reference. Protein stain: amido black B. 

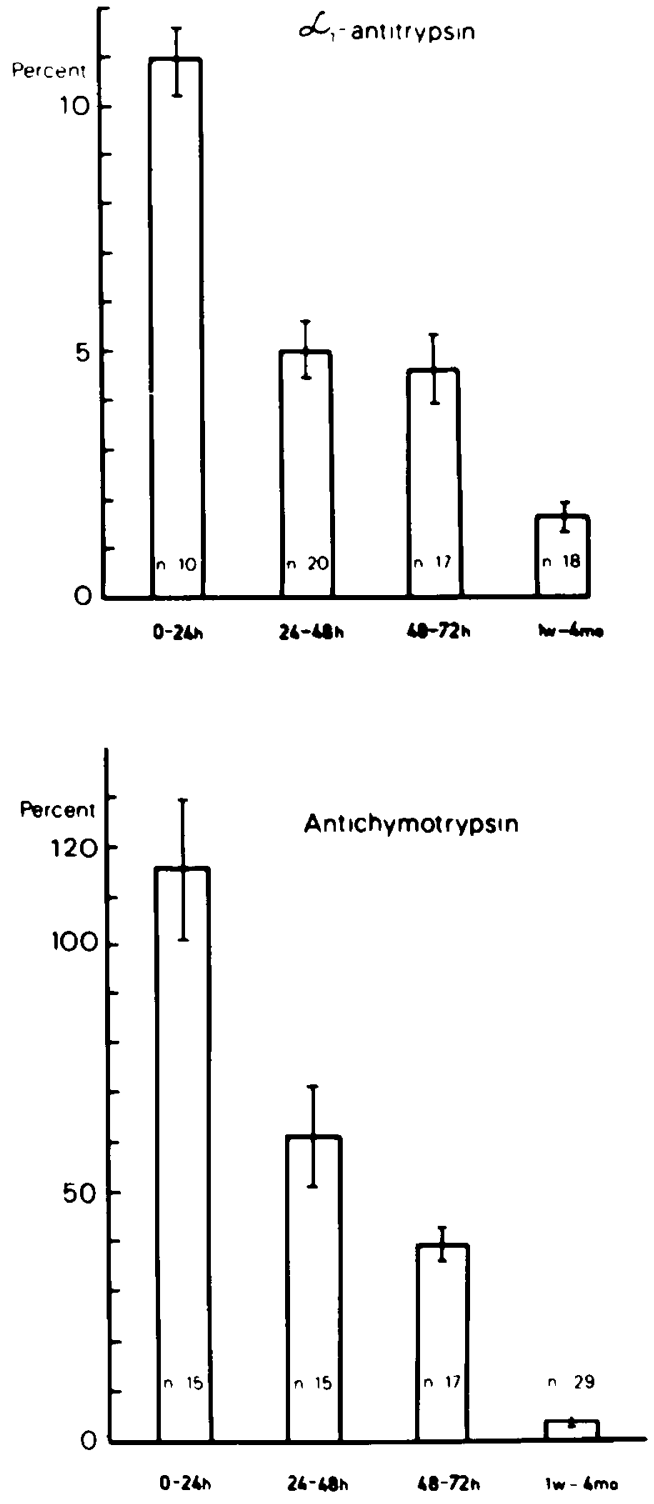

TIME AFTER DELIVERY

Fig. 3. Content of $\alpha_{1}$-antitrypsin and antichymotrypsin in human milk from various times after delivery in relation to the content in adult human serum. (100\% means $1.35 \mathrm{~g} \alpha_{1}$-antitrypsin/liter and $0.5 \mathrm{~g}$ antichymotryp$\sin /$ liter.) $\%$, mean value \pm SEM.

$\alpha_{1}$-antitrypsin was previously found in human milk (15). In the present study, crossed immunoelectrophoresis demonstrated $\alpha_{1^{-}}$ antitrypsin in the same region where the protease inhibiting activity was found. This agrees with the findings of Barkholt Pedersen et al. (2). Using gel chromatography, they found only one peak of antitrypsin activity in human colostrum. This peak had an elution volume close to that of serum albumin. They also found that the trypsin inhibitor, like $\alpha_{1}$-antitrypsin, was destroyed by trichloroacetic acid and had a low stability below pH 5.5 .

Crossed immunoelectrophoresis demonstrated two components of antichymotrypsin in human milk. The minor component had the same mobility as antichymotrypsin in plasma, whereas the major one had a slower mobility. Possibly, it represents a complex formation between a protease and antichymotrypsin.

In Ist-day milk, the concentration of antichymotrypsin was the same as in adult serum; and in contrast to serum the absolute amounts were higher than those of $\alpha_{1}$-antitrypsin. The amount of antichymotrypsin decreased and was somewhat lower than that of $\alpha_{1}$-antitrypsin at 1 week or later after delivery. In this context, it is of interest to note that in pulmonary secretions the relative concentration of antichymotrypsin is higher than for $\alpha_{1}$-antitrypsin $(28,30)$.

The trypsin inhibiting capacity of human milk is much lower than that of porcine and bovine colostrum. One $\mathrm{ml}$ of the 1st-day colostrum from the pig inhibits about $2000 \mu \mathrm{g}$ and from the cow about $600 \mu \mathrm{g}$ of trypsin, whereas the corresponding figure for human milk from the first 3 days is $20-60 \mu \mathrm{g}(2,17,21,22)$. Laskowski and Laskowski (22) could not detect any inhibitor on the 5th day, and Hyanek et al. (17) reported low values (0-20 $\mu \mathrm{g})$ on the 6th day. The present study obtained somewhat higher values. The differences, which are small, could well be explained by the use of different methods. For comparison, Zoppi et al. (32) reported a trypsin content in duodenal juice at birth of about 120 $\mu \mathrm{g} / \mathrm{ml}$ (during $50 \mathrm{~min}$ after pancreozymin and secretin); $24 \mathrm{hr}$ after first feeding about $75 \mu \mathrm{g} / \mathrm{ml}$; and at 1 week about $200 \mu \mathrm{g} / \mathrm{ml}$. Similar to Hyanek et al. (17), we could detect trypsin inhibitory activity in $50 \%$ of the milk samples from the 1st day, in $75 \%$ from the $2 \mathrm{nd}$, and in 12 of 13 from the 3rd day. All samples from 1 week after delivery and later showed a trypsin inhibitory activity. This inhibiting activity was exerted by $\alpha_{1}$-antitrypsin. Chymotrypsin inhibiting activity exerted by antichymotrypsin was observed in half of the milk samples from the first 2 days, and only occasionally in milk from day 3 or later.

$\alpha_{1}$-antitrypsin and antichymotrypsin were at the same time immunochemically present in "normal" amounts. The reason for this discrepancy is obscure, but various degrees of complex formation between the inhibitors and proteolytic enzymes occurring in human milk might be responsible.

The decrease in the concentration of $\alpha_{1}$-antitrypsin and antichymotrypsin during the lst week coincides with the decrease in the concentration of other proteins in human milk. However, the amount of the milk increases; therefore, the total amount of $\alpha_{1}$ antitrypsin per meal received by the infant during the whole lactation period remains about the same.

From this and from previous studies (2), it can be concluded that the demonstrated protease inhibitory capacity of human milk can be mainly ascribed to the $\alpha_{1}$-antitrypsin. The physiologic role of the protease inhibitors in human milk is obscure. One role might be to inhibit proteolytic enzymes liberated from the leucocytes occurring in human milk. Possibly, the protease inhibitors might contribute to the local immunity in the lumen of the gut and might favor the enhanced intestinal absorption of macromolecules (proteins) in early infancy.

\section{REFERENCES AND NOTES}

1. Baintner, $\mathrm{K}$., Jr.: Urinary excretion of colostral trypsin inhibitor in neonatal pigs. Life Sci., 9: 847 (1970)

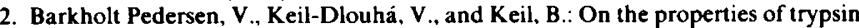
inhibitors from human and bovine colostrum. FEBS Letters, 17: 23 (1971)

3. Brambell, R. F. W.: The transmission of passive immunity from mother to young. (North Holland Publishing Company, Amsterdam, London, 1970)

4. Carlsson, L., and Karlsson. B.: Gel diffusion methods for determination of protease and protease-inhibiting activities. Experientia, 28: 990 (1972)

5. Carlsson, L. C. T., and Karlsson, B. W.: Electrophoretically separable trypsin inhibitors of the developing pig. Enzyme, 14: 261 (1972-73)

6. Carlsson, L. C. T., and Karlsson, B. W.: Trypsin inhibiting capacity in the serum, digestive contents, urine and organs of the developing pig. Enzymologia, 43: 89 (1972)

7. Carlsson, L. C. T., Karlsson, B. W., and Weström. B.: Trypsin inhibition in serum and urine of neonatal and lactating rats and in rat colostrum and milk. Int. J. Biochem., 6: 173 (1975)

8. Carlsson, L. C. T., Bergelin. J. S. S., and Karlsson, B. W.: Trypsin inhibition in urine of developing neonatal pigs and in sow's colostrum. Enzyme, 18: 176 (1974)

9. Ćechová, D.: Isolation of isoinhibitors from cow colostrum by affinity chromatography on column of trypsin-sepharose 4 B. Collect. Czech. Chem. Commun., 39: 647 (1973)

10. Ćechová, D., Jonáková, V., and Sorm, F.: Primary structure of trypsin inhibitor from cow colostrum (component B2). Collect. Czech. Chem. Commun., 36: 3342 (1971)

11. Fagerhol, M. K., and Laurell, C. B.: The Pi-system-inherited variants of serum $\alpha_{1}$-antitrypsin. In: A Steinberg, A. Bearn: Progress in Medical Genetics. Vol. 7, p. 96-111 (Grune \& Stratton, London, 1970)

12. Fritz, H., Hartwich, G., and Werle, E.: Isolierung und Charakterizierung des Trypsininhibitors aus Pankreasgewebe und Pankreassekret vom Hund. Hoppe Seyler's Z. Physiol. Chem., 345: 150 (1966)

13. Ganrot, P. O.: Crossed immunoelectrophoresis. Scand. J. Clin Lab. Invest., 29 (suppl 124): 39 (1972) 
14. Gugler, E., and von Muralt, G.: Über immunoelectrophoretische Untersuchungen an Frauen milch proteinen. Schweiz, Med. Wschr., 89: 925 (1959)

15. Hanson, L. A.: The serological relationship between human milk and blood plasma. Int. Arch. Allerg., 17: 45 (1960)

16. Heyndrickx, G. V.: Further investigations on the enzymes in human milk Pediatrics, 31: 1019 (1963)

17. Hyánek, von J., Nosková, R., and Cafour Ková, Z.: Die Trypsin-Inhibitoraktivität der Muttermilch in der ersten Wocke nach der Entbindung. Ann. Paediatr. 204: 125 (1965)

18. Johansson, B. G.: Agarose gel electrophoresis. Scand. J. Clin. Lab. Invest., 29 (suppl 124): 7 (1972)

19. Kiermeier, F., and Semper, G.: Über das Vorkommen eines proteolytischen Enzyms und eines Trypsin-Inhibitors in Kuhmilch. II. Milleilung. Zur inhibitorischen Wirkung. Z. Lebensm. Unters. Forsch., 111: 373 (1960)

20. Krees, L. F., Martin, S. R., and Laskowski, M., Sr.: Isolation of isoinhibitors of trypsin from porcine colostrum. Biochim. Biophys. Acta. 229: 836 (1971)

21. Laskowski, M., Kassel, B., and Hagerty, G.: A crystalline trypsin inhibitor from swine colostrum. Biochim. Biophys. Acta, 24: 300 (1957)

22. Laskowski, M., Jr., and Laskowski, M.: Crystalline trypsin inhibitor from colostrum. J. Biol. Chem., 190: 563 (1951)

23. Laurell. C. B.: Antigen-antibody crossed electrophoresis. Anal. Biochem., 10: 358 (1965)

24. Laurell, C. B.: Electroimmoassay. Scand. J. Clin. Lab. Invest., 29 (suppl. 124): 21 (1972)

25. Laurell, C. B.: Quantitative estimation of proteins by electrophoresis in agarose gel containing antibodies. Anal. Biochem., 15: 45 (1966)

26. Laurell, C. B and Jeppsson, J. O. Protease inhibitors in plasma. In: F. W. Putman: The Plasma Proteins. 2nd Edition (Academic Press, New York, 1975)

27. Pineiro, A., Ortega, F., and Uriel, J.: Trypsin inhibitor from cow colostrum. Isolation, electrophoretic characterization and immunologic properties. Biochim. Biophys. Acta, 379: 201 (1975)

28. Ryley, H. C., and Brogan, T. D.: Quantitative immunoelectrophoretic analysis of the plasma proteins in the sol phase of sputum from patients with chronic bronchitis. J. Clin. Pathol., 26: 852 (1973)

29. Sharp, H. L.: The current status of $\alpha_{1}$-antitrypsin, a protease inhibitor, in gastrointestinal disease. Gastroenterology, 70:611 (1976)

30. Tegner, H.: Quantitation of human granulocyte protease inhibitors in nonpurulent bronchial lavage fluids. Acta Otolaryngol., 85: 282 (1978)

31. Weström, B. R., and Carlsson, L. C. T.: Trypsin inhibitors in serum of adult and suckling rats and in rat milk. Int. J. Biochem., 7: 41 (1976)

32. Zoppi, G., Andreotti, G., Pajno-Ferrara, F., Njai, D. M., and Gaburro, D.: Exocrine pancreas function in premature and full term neonates. Pediatr. Res., 6: 880 (1972)

33. The authors thank Mrs. B. Benediktsson for excellent technical assistance.

34. This research was supported in part, by the Swedish Medical Research Council (project nr 5143).

35. Requests for reprints should be addressed to: Tor Lindberg. M. D., Department of Pediatrics, Malmö General Hospital, S-214 01 Malmö, Sweden.

36. Received for publication May 23, 1978.

37. Accepted for publication August 23, 1978. 